\title{
Clostridium perfringens: a review of the disease in pigs, horses and broiler chickens
}

\author{
Clostridium perfringens: uma revisão da doença em suínos, equinos e frangos de corte
}

\author{
Rodrigo Otávio Silveira Silva ${ }^{\mathrm{I}^{*}}$ Carlos Augusto Oliveira Junior ${ }^{\mathrm{I}}$ \\ Roberto Maurício Carvalho Guedes ${ }^{\mathrm{I}}$ Francisco Carlos Faria Lobato
}

\section{- REVIEW -}

\section{ABSTRACT}

Clostridium perfringens is a gram-positive, anaerobic fermentative, spore-forming bacillus that may be found in the environment but is more commonly found as part of the microbiota of humans and animals. The bacterium is considered a common enteric pathogen; however, the pathogenesis and predisposing factors of the disease can differ among species. Therefore, specific studies are necessary for understanding the role of this pathogen, how to diagnose it and which control measures are applicable. The aim of this paper is to review the current knowledge regarding $\boldsymbol{C}$. perfringens infections in pigs, horses and broiler chickens.

Key words: diarrhea, enteritis, equine, swine, poultry.

RESUMO

Clostridium perfringens é um bacilo anaeróbio, Gram positivo, formador de esporos que pode ser encontrado no ambiente e, principalmente, como parte da microbiota de humanos e animais. É considerado um patógeno entérico comum, mas a patogênese e os fatores predisponentes da doença normalmente diferem entre as espécies, sendo necessários estudos especificos para compreender os mecanismos de ação do patógeno, como diagnosticá-lo e apresentar quais as medidas de controle são aplicáveis. $O$ objetivo deste trabalho é revisar as atuais descobertas a respeito da infecção de $\boldsymbol{C}$. perfringens em suinos, equinos e frango de corte.

Palavras-chave: diarreia, enterite, equinos, suinos, aves domésticas.

\section{INTRODUCTION}

Clostridia produce the largest number of toxins of any type of bacteria. Among Clostridium species, $\boldsymbol{C}$. perfringens is the major toxin producer and is also the most widespread, being found as part of the microbiota of animals and humans and also in soil. The microorganism was first named Bacillus aerogenes capsulatus, then Clostridium welchii and finally $\boldsymbol{C}$. perfringens.

C. perfringens is a gram-positive, anaerobic, fermentative, spore-forming bacillus that is classified into five types according to the production of four major toxins: alpha $(\alpha)$, beta $(\beta)$, epsilon $(\varepsilon)$ and iota (1) (Table 1). In addition to the major toxins, $\boldsymbol{C}$. perfringens can produce more than 15 other known toxins. Some of these additional virulence factors, including enterotoxin, necrotic enteritis like-B toxin (NetB) and beta-2 toxin, have received more attention than others, most likely due to their role in the pathogenesis of $\boldsymbol{C}$. perfringensassociated disease (CPAD) in humans and animals (POPOFF \& BOUVET, 2013).

C. perfringens is recognized as one of the most important causes of foodborne disease in humans and is also commonly involved in human and animal cases of gas gangrene (TAYLOR, 1999; MIYAMOTO et al., 2012). In veterinary medicine, $\boldsymbol{C}$. perfringens is responsible for several, mostly enteric, diseases. In the last few years, significant progress in the understanding of $\boldsymbol{C}$. perfringens in animals was achieved (UZAL et al., 2014). There are some reviews about the current knowledge in ruminants and also in small animals, but the literature lacks in reviews about $\boldsymbol{C}$. perfringens infection in other species. In

\footnotetext{
'Escola de Veterinária, Universidade Federal de Minas Gerais (UFMG), Av. Antônio Carlos, 6627, 31270-901, Belo Horizonte, MG, Brasil. E-mail: rodrigo.otaviosilva@gmail.com. *Corresponding author. 
Table $1-\boldsymbol{C}$. perfringens types, production of major toxins and other additional virulence factors.

\begin{tabular}{|c|c|c|c|c|c|c|c|}
\hline \multirow{2}{*}{$C$. perfringens type } & \multicolumn{4}{|c|}{---1 } & \multicolumn{3}{|c|}{------------- Additional virulence factors (gene) ------ } \\
\hline & Alpha $(p l c)$ & Beta $(c p b)$ & Epsilon (etx) & Iota (iap) & Enterotoxin (cpe) & NetB (netB) & Beta-2 (cpb2) \\
\hline A & + & - & - & - & $+/-$ & $+/-$ & $+/-$ \\
\hline B & + & + & - & - & $+/-$ & - & $+/-$ \\
\hline $\mathrm{C}$ & + & + & - & - & $+/-$ & - & $+/-$ \\
\hline $\mathrm{D}$ & + & - & + & - & $+/-$ & - & $+/-$ \\
\hline E & + & - & - & + & $+/-$ & - & $+/-$ \\
\hline
\end{tabular}

Adapted from POPOFF \& BOUVET (2013).

addition, there is no review about current studies with $\boldsymbol{C}$. perfringens in Brazil. Here, it is reviewed the most recent advances in the understanding of C. perfringens disease in pigs, horses and broiler chickens, also focusing in studies conducted in Brazil.

\section{Swine}

C. perfringens type A is considered by some researchers as the main cause of neonatal diarrhea in piglets (SONGER \& UZAL, 2005; CHAN et al., 2012). However, the pathogenesis of this bacterium in swine remains unclear, leading to some difficulties in the diagnosis and also making it impossible to determine its true prevalence.

C. perfringens type A commonly affects neonates in the first week of life. Once it is part of the microbiota in swine, sows can transfer this bacterium to piglets. The disease is described as a nonhemorrhagic mucoid diarrhea and is characterized by mucosal necrosis and villus atrophy, without attachment and invasion by the microorganism (SONGER \& UZAL 2005). According to some studies, lesions may also be absent; in light of this, some groups have stated that $\boldsymbol{C}$. perfringens diarrhea in neonatal piglets might be secretory (SONGER \& UZAL, 2005; CRUZ-JUNIOR et al., 2013).

In the late 1990s, it was shown that $\boldsymbol{C}$. perfringens strains positive for the beta- 2 gene (cpb2) were more frequent in diarrheic piglets than in healthy piglets (GILBERT et al., 1997; KLAASEN et al., 1999). Thus, $c p b 2$ was used as a virulence factor marker for the diagnosis of $\boldsymbol{C}$. perfringens type A diarrhea in swine. However, some recent results, including one study performed on Brazilian farms, showed no differences between the prevalence of cpb2-positive strains in diarrheic and non-diarrheic piglets (WOLLSCHLÄGER et al., 2009; CRUZJUNIOR et al., 2013; FARZAN et al., 2013). In addition, molecular studies showed a slight difference in the genetic composition and activity of $c p b 2$-positive swine isolates (JOST et al., 2006a; JOST et al., 2006b). Taken together, these recent results suggest that beta2 toxin is not important for $\boldsymbol{C}$. perfringens diarrhea in piglets and also that the use of $c p b 2$ as a virulence factor marker is not appropriate for diagnosis.

Therefore, the diagnosis of CPA infection in swine is challenging. Most authors agree that the clinical signs of clostridial diarrhea are similar to those of several other enteric diseases; it is also still not possible to differentiate between pathogenic $\boldsymbol{C}$. perfringens type $\mathrm{A}$ and $\boldsymbol{C}$. perfringens type $\mathrm{A}$ that is part of the microbiota (SONGER \& UZAL, 2005). Accordingly, the presumptive diagnosis of CPA infection in piglets should be based on a combination of the isolation of $\boldsymbol{C}$. perfringens and the absence of histological lesions (or laboratory detection) of other enteropathogens, such as rotavirus, enterotoxigenic Escherichia coli, C. difficile and Isospora suis. Even with this approach, most pathologists have expressed reservations about making a diagnosis of CPA enteritis. In addition to the difficulty in diagnosing CPA infection in piglets, a recent survey showed that practitioners generally diagnose the disease only according to the age of onset of diarrhea (between 1 and 7 days old) and that they also report a high confidence in their diagnosis method (CHAN et al., 2013).

C. perfringens type $\mathrm{C}$ is also well known as a swine pathogen and is characterized by hemorrhagic necrotic enteritis in neonatal piglets, mostly in animals from one to four days old. This age is commonly affected because of the low secretion of trypsin in the gut, which in adults commonly inactivates the beta toxin. In addition, the colostrum contains protease inhibitors, which could also prevent the degradation of beta toxin in the gut of neonatal animals (NIILO, 1988; SONGER \& UZAL, 2005).

Beta toxin, produced by $C$. perfringens type $C$, induces vascular necrosis, hemorrhage and subsequent hypoxic tissue necrosis (MICLARD et al., 2009). In light of this, affected piglets commonly 
show bloody diarrhea and hemorrhagic necrotic enteritis in the small intestine. In contrast with $\boldsymbol{C}$. perfringens type A lesions, deep intestinal layers can be necrotic. The known clinical signs in association with macroscopic and histological alterations and isolation of $\boldsymbol{C}$. perfringens type $\mathrm{C}$ from the intestinal contents strongly suggest necrotic enteritis by this agent; nonetheless, the detection of beta toxin is necessary for a confirmatory laboratory diagnosis (SONGER \& UZAL, 2005).

Commercial vaccines containing beta toxoids, which provide passive immunity to piglets via the colostrum, appear to be efficient for controlling $\boldsymbol{C}$. perfringens type $\mathrm{C}$ diarrhea in swine (SCHAFER et al., 2012). The use of autogenous toxoids for the prevention of CPA-associated diarrhea has been reported in some studies (SONGER \& GLOCK, 1998; HAMMER et al., 2008); however, thus far, there is no evidence of their efficacy in preventing disease. Some authors have also reported the efficiency of toxoids or recombinant immunogens containing alpha and/or beta- 2 toxins for inducing antibodies in swine (SPRINGER et al., 2012; SALVARANI et al., 2013). Regardless, the presence of antibodies does not confirm that these vaccines would be able to prevent the disease in an experimental model or in the field. It is also important to note that a piglet model of CPA diarrhea has not yet been developed; furthermore, the evaluation of a toxoid in a natural infected herd is difficult because other management variables are often present.

Despite vaccination, the prevention of CPA-associated diarrhea is commonly achieved by maximizing colostrum uptake by piglets and reducing this and other pathogens in the environment. This includes washing the sow prior to farrowing, the routine disinfection of farrowing rooms and the use of antimicrobials in the sow's feed during the prefarrowing period. Finally, in cases of disease onset, injectable antibiotics are an option for the treatment of piglets; bacitracin, lincomycin, sulfa-trimethoprim and tylosin are commonly used in feed, whereas penicillin is an injectable drug commonly used in the field (SONGER \& GLOCK, 1998). Studies from several countries, including Brazil, have shown that most $\boldsymbol{C}$. perfringens isolates from piglets are resistant to tylosin and oxytetracycline, although resistance to beta-lactam antibiotics has not been detected until recently (TANSUPHASIRI et al., 2005; SLAVIĆ et al., 2011: SALVARANI et al., 2012).

Horses

C. perfringens type $\mathrm{C}$ is one of the most important causes of enteric infection in foals
(BUESCHEL et al., 2003). This enterotoxemia is more common in neonatal animals, but older foals and adult horses can also be affected. The disease is acute, characterized by bloody diarrhea, and commonly fatal due to the absorption of toxins into systemic circulation. On post mortem examination, the small intestine, and eventually also the large intestine, is diffusely hemorrhagic and necrotic, sometimes with the presence of ulcers and pseudomembrane. Mucosal and submucosal thrombosis is also common (HOWARD-MARTIN et al., 1986; DROLET et al., 1990; DIAB et al., 2012).

For neonatal foals, the main predisposing factor is similar to that cited for young piglets: a typically low trypsin secretion associated with colostrum intake. For older foals or adult horses, the predisposing factors are not completely known; however, malnutrition, trypsin deficiency, pancreatic diseases and a diet rich in trypsin inhibitors may predispose an animal to $\boldsymbol{C}$. perfringens type $\mathrm{C}$ infection (DIAB et al., 2012). Some authors also reported that certain antibiotics could play a role in C. perfringens type $\mathrm{C}$ infection, although this is only speculative (DIAB et al., 2012). Co-infection of $\boldsymbol{C}$. perfringens type $\mathrm{C}$ and $\boldsymbol{C}$. difficile, another common clostridial foal enteropathogen, could also be possible (UZAL et al., 2012).

The laboratory diagnosis of $\boldsymbol{C}$. perfringens type $\mathrm{C}$ infection in horses is similar to that in other species and is based on the detection of beta toxin in the intestinal contents in association with post mortem findings when death occurs. The absence of bloody diarrhea does not exclude the diagnosis of $\boldsymbol{C}$. perfringens type $\mathrm{C}$ infection, as some animals can show acute colic without diarrhea or even sudden death (DIAB et al., 2012). Because $\boldsymbol{C}$. perfringens type $\mathrm{C}$ is rare as part of the microbiota of horses, the isolation of this microorganism in combination with the typical lesions has a high diagnostic value. However, it is possible that $\boldsymbol{C}$. perfringens type $\mathrm{C}$ may not be isolated, leading to some toxin-positive but isolation-negative cases. This might be due to the growth of $\boldsymbol{C}$. perfringens type $\mathrm{C}$ in only some intestinal segments, leading to lesions and enterotoxemia despite a lack of the microorganism in the content of some segments (SONGER, 1996; DIAB et al., 2012).

C. perfringens type $\mathrm{A}$ is also implicated as a cause of diarrhea in adult horses and foals (HAZLETT et al., 2011; DIAB et al., 2012). It is well known that healthy equines can harbor $C$. perfringens type A strains, but studies have shown that diarrheic animals are more likely to be positive for the isolation of this microorganism than healthy horses and foals 
(NETHERWOOD et al., 1996; SCHOSTER et al., 2012; SILVA et al., 2013a). Additionally, the cpb2 gene was found to be more common in horses with intestinal disorders compared with healthy animals or those that were hospitalized for reasons other than intestinal problems (GIBERT et al., 1998; HERHOLZ et al., 1999). In another study, BACCIARINI et al. (2003) reported that beta-2 toxin was more common in horses with gastrointestinal disease than in control horses (from a slaughterhouse), as demonstrated by immunohistochemistry. There was also a significant correlation between the isolation of $c p b 2$-harboring C. perfringens and the identification of beta- 2 toxin in the intestinal content (BACCIARINI et al., 2003). One possible predisposing factor could be antibiotic treatment with aminoglycoside antibiotics, as a previous study showed an association between the lethal progression of colitis associated with cpb2positive $\boldsymbol{C}$. perfringens and antibiotic treatment (gentamicin-penicillin). Additionally, an in vitro experiment showed that gentamicin could induce beta-2 toxin production in $\boldsymbol{C}$. perfringens beta2 isolates from horses (HERHOLZ et al., 1999; VILEI et al., 2005). In foals, HAZLETT et al. (2011) recently reported a beta- 2 toxigenic $C$. perfringens type A colitis in a three-day-old animal. The animal experienced a worsening of the clinical signs after treatment with gentamicin. Colitis and typhlitis were observed in the post mortem examination, and an abundance of cpb2-positive $\boldsymbol{C}$. perfringens was isolated from both the small and large intestines. In this case, other enteropathogens were absent, suggesting that $\boldsymbol{C}$. perfringens was responsible for the intestinal disease.

In addition to beta- 2 toxin, WEESE et al. (2001) reported an association between gastrointestinal disease and the presence of enterotoxin in stool samples from mature horses and foals. However, the actual roles of both toxins have remained unclear, and some recent studies, including one with horses from Minas Gerais and Sao Paulo States in Brazil, showed no differences in the isolation rates of $c p b 2$ and cpe-harboring $\boldsymbol{C}$. perfringens among animals with gastrointestinal disease or a control group (SILVA et al., 2013a: SCHOSTER et al., 2013). In fact, further studies are needed to confirm the role of these toxins in the development of gastrointestinal disease in horses and also to determine whether they could be used in the diagnosis of $\boldsymbol{C}$. perfringens type A infection in equines.

Studies on the antimicrobial susceptibility of $\boldsymbol{C}$. perfringens isolates from equines have shown a high susceptibility to penicillin, vancomycin, chloramphenicol and metronidazole. In contrast, resistance to macrolides (commonly erythromycin) and oxytetracycline is common (SILVA et al., 2013; LAWHON et al., 2013). It is also important to remember that, despite the high susceptibility, some studies suggest that exposure to gentamicin and penicillin could predispose equines to $C$. perfringens type A infection (HERHOLZ et al., 1999; VILEI et al., 2005; HAZLETT et al., 2011)

Similar to the reports for swine, the vaccination of mares with beta toxoid to prevent type-C enterotoxemia in foals is common in some countries, although studies regarding the immune response of equines to this or other clostridial antigens are rare (TIMONEY et al., 2005). Considering that the main virulence factors involved in $C$. perfringens type $\mathrm{A}$ infection in equines are still unknown, no conclusions can be made regarding the composition of a vaccine to prevent this infection.

\section{Broiler chickens}

Necrotic enteritis (NE) is caused by $\boldsymbol{C}$. perfringens type A and, more uncommonly, by $\boldsymbol{C}$. perfringens type $\mathrm{C}$. NE is one of the most common infectious diseases in poultry, resulting in an estimated annual economic loss of more than $\$ 2$ billion, largely related to impaired growth performance (COOPER et al., 2009; VAN IMMERSEEL et al., 2009). This enteric infection is commonly well controlled by anticoccidials or antibiotic growth promoters, but the use of these compounds has been banned in animal feed in the European Union, and there is pressure to reduce their use worldwide because of the risk of multiple antimicrobial-resistant strains (VAN IMMERSEEL et al., 2009). Thus, NE is re-emerging as an important disease in poultry, and there is concern about the increased risk of contamination of poultry products for human consumption, as $\boldsymbol{C}$. perfringens is one of the most common causes of foodborne illness worldwide (NOWELL et al., 2010; CDC, 2012)

Little is known about the susceptibility of poultry lines to NE; however, a recent study suggests that Cobb chickens are more susceptible to necrotic enteritis compared with Ross and Hubbard chickens (JANG et al., 2013). The disease occurs mostly in animals between 2-6 weeks of age and can vary from an acute to a subclinical form. The subclinical form is more prevalent, being responsible for the greatest economic losses in poultry production due to NE, and is characterized by chronic intestinal mucosal damage, which leads to poor digestion and absorption (LONG, 1973; VAN IMMERSEEL et al., 2009; TIMBERMONT et al., 2011). In this case, hepatitis 
or cholangiohepatitis is often found at processing, leading to an increase in liver condemnation (LEE et al., 2011). The acute form is less common and is characterized by a sudden increase in mortality, which can reach 50\% (RIDDELL \& KONG, 1992; TIMBERMONT et al., 2011).

The pathogenesis of NE is not completely understood. Several years ago, it was believed that alpha toxin was the main virulence factor involved in these cases, although some recent studies have shown that this is not completely true (MCCOURT et al., 2005; BUESCHEL et al., 2003). In one these studies, KEYBURN et al. (2006) showed that an alpha toxin null mutant was able to produce NE lesions in a chicken experimental model, suggesting that alpha toxin might contribute to the lesions but is not essential for the development of the disease. It has also been speculated that beta- 2 and enterotoxin are involved in NE, but there is little evidence that both toxins are involved (VAN IMMERSEEL et al., 2009; CRESPO et al., 2007).

Several studies have investigated the role of other toxins in NE. One of the most interesting of these is Necrotic Enteritis toxin B (NetB), a poreforming toxin capable of causing lesions typical of $\mathrm{NE}$ in experimental models (KEYBURN et al., 2008). In addition, it was demonstrated that the NetB-encoding gene (netb) is common in $\boldsymbol{C}$. perfringens type A isolates from NE birds, whereas it is rare in healthy birds (KEYBURN et al., 2008). A similar association was recently reported in turkeys: netb was identified in $6.6 \%$ of the $\boldsymbol{C}$. perfringens strains isolated from turkeys with NE but in none of the strains isolated from healthy animals (LYHS et al., 2013). Because reports have indicated that $\boldsymbol{C}$. perfringens netbnegative strains can cause NE, it appears that there are other virulence factors involved (LEE et al., 2011).

Several predisposing factors for NE have been identified. One of the most important is nutrition: any diet that may lead to a decrease in nutrient digestibility and a reduction in intestinal transit may predispose an animal to overgrowth of C. perfringens in the gut. For instance, diets with a high concentration of water-soluble, non-starch polysaccharides or poorly digestible proteins are commonly incriminated in NE cases (COOPER \& SONGER, 2009; LEE et al., 2011). Coccidiosis is also a well-known predisposing factor due to mucosal damage, which leads to plasma leakage into the gut. Additionally, the immune response to coccidial infection increases the amount of mucus in the intestinal tract; both mucus and plasma are used as a substrate by $\boldsymbol{C}$. perfringens (COLLIER et al., 2008).
Some studies have also indicated that, in addition to all other predisposing factors, the presence of poultry pathogenic $\boldsymbol{C}$. perfringens strains is necessary for the occurrence of the disease. In fact, different genotypes are present in healthy flocks, whereas a single clonal strain is generally disseminated among birds in flocks with NE. After treatment, the birds can again carry multiple genetic types. These results were confirmed by pulsed-field electrophoresis, by multilocus sequence typing analysis and also in an experimental model (ENGSTRÖM et al., 2003; NAUERBY et al., 2003; BARBARA et al., 2008). A recent study evaluating netb-positive $\boldsymbol{C}$. perfringens identified a specific chromosomal locus in these strains, suggesting that this chromosomal background can confer a selective advantage to NE-causing strains, possibly through mechanisms involving iron acquisition, carbohydrate metabolism or even plasmid maintenance (LEPP et al., 2013).

The isolation of C. perfringens alone is not sufficient for diagnosis because this bacterium is commonly part of the microbiota; however, the absence of $\boldsymbol{C}$. perfringens can rule out the involvement of this agent (COOPER et al., 2013). Based on recent reports describing the association of netb and NE, the detection of this gene might also be interesting for a complete laboratory diagnosis (KEYBURN et al., 2008). Intestinal damage and increases in liver condemnation during slaughterhouse inspections strongly suggest NE. The lesions are commonly restricted to the small intestine, which is filled with gas and has thin walls. Confluent mucosal necrosis may be observed, sometimes also covered by a pseudomembrane (COOPER et al., 2013). Histological evaluation is important for confirming typical lesions and also to rule out the involvement of other possible enteropathogens, including coccidial infection, ulcerative colitis by $\boldsymbol{C}$. colinum and histomoniasis (TIMBERMONT et al., 2011; COOPER et al., 2013). The lesions can vary depending on the stage of the infection. In early stages, a strong inflammatory reaction with heterophilic granulocytes in the lamina propria may be observed, whereas in later stages, diffuse coagulative necrosis of the mucosa may be present, with gram-positive rods associated with the lesions but not invading the epithelium (TIMBERMONT et al., 2011).

Several proteins have been evaluated as immunogens against NE. Most studies have addressed the effect of vaccines containing alpha toxin (commonly as a toxoid or in a recombinant form), but the results vary widely in the literature. In general, vaccinated birds were found to be more resistant to 
challenge compared with a control group, but the vaccines were not able to prevent lesions (LEE et al., 2011). Recently, studies with a NetB recombinant protein showed that the vaccination of poultry or maternal immunization can partially protect broiler chickens from necrotic enteritis (KEYBURN et al., 2013a; KEYBURN et al., 2013b). Considering the pressure to reduce or ban growth promoters from animal feed, the development of a potent vaccine against NE might be an important step for poultry production in the next few years.

\section{CONCLUSIONS}

C. perfringens is well recognized as an important enteric pathogen for all domestic species. Specifically for broiler chicken, some recent advances have been made in the pathogenesis and diagnosis of $\boldsymbol{C}$. perfringens infection. On the other hand the current knowledge regarding this bacterium in pigs and horses is still clouded.

\section{REFERENCES}

BACCIARINI, L.N. et al. Immunohistochemical localization of Clostridium perfringens beta2-toxin in the gastrointestinal tract of horses. Veterinary Pathology, v.40, n.4, p.376-381, 2003. Available from: $<$ http://www.ncbi.nlm.nih.gov/pubmed/12824509>. Accessed: Out. 29, 2014. doi: 10.1354/vp.40-4-376.

BARBARA, A.J. et al. Necrotic enteritis-producing strains of Clostridium perfringens displace non-necrotic enteritis strains from the gut of chicks. Veterinary Microbiology, v.126, n.4, p.377-382, 2008. Available from: <http://www.ncbi.nlm.nih.gov/ pubmed/17850994>. Accessed: Out. 29, 2014.

BUESCHEL, D. et al. Prevalence of cpb2, encoding beta2 toxin, in Clostridium perfringens field isolates: correlation of genotype with phenotype. Veterinary Microbiology, v.94, n.2, p.121-129, 2003. Available from: <http://www.ncbi.nlm.nih. gov/pubmed/12781480>. Accessed: Out. 29, 2014. doi: 10.1016/ S0378-1135(03)00081-6.

CENTERS FOR DISEASE CONTROL AND PREVENTION (CDC). Fatal foodborne Clostridium perfringens illness at a state psychiatric hospital--Louisiana, 2010. Morbidity and Mortality Weekly Report, v.61, n.32, p.605-608, 2012.

CHAN, G. et al. The epidemiology of Clostridium perfringens type A on Ontario swine farms, with special reference to cpb2positive isolates. BMC Veterinary Research, v.8, p.156, 2012. Available from: <http://www.ncbi.nlm.nih.gov/pubmed/22947389>. Accessed: Out. 29, 2014. doi: 10.1186/1746-6148-8-156.

COLLIER, C.T. et al. Coccidia-induced mucogenesis promotes the onset of necrotic enteritis by supporting Clostridium perfringens growth. Veterinary Immunology and Immunopathology, v.122, n.1-2, p.104-115, 2008. Available from: <http://www.ncbi. nlm.nih.gov/pubmed/18068809>. Accessed: Out. 29, 2014. doi: $10.1177 / 1040638713483468$.

COOPER, K.K. et al. Diagnosing clostridial enteric disease in poultry. Journal of Veterinary Diagnostic Investigation, v.25, n.3, p.314-327, 2013. Available from: <http://www.ncbi.nlm.nih. gov/pubmed/23572451>. Accessed: Out. 29, 2014.

COOPER, K.K.; SONGER J.G. Necrotic enteritis in chickens: a paradigm of enteric infection by Clostridium perfringens type A. Anaerobe, v.15, n.1-2, p.55-60, 2009. Available from: <http:// www.ncbi.nlm.nih.gov/pubmed/19186215>. Accessed: Out. 29, 2014. doi: 10.1016/j.anaerobe.2009.01.006.

COOPER, K.K. et al. Immunization with recombinant alpha toxin protects broiler chicks against experimental challenge with Clostridium perfringens. Veterinary Microbiology, v.133, p.9297, 2009. Available from: <http://www.sciencedirect.com/science/ article/pii/S0378113508002150>. Accessed: Out. 29, 2014. doi: 10.1016/j.vetmic.2008.06.001.

CRESPO, R. et al. Toxinotypes of Clostridium perfringens isolated from sick and healthy avian species. Journal of Veterinary Diagnostic Investigation, v.19, n.3, p.329-333, 2007. Available from: $<$ http://www.ncbi.nlm.nih.gov/pubmed/17459870>. Accessed: Out. 29, 2014. doi: 10.1177/104063870701900321.

CRUZ-JUNIOR, E.C. et al. A surveillance of enteropathogens in piglets from birth to seven days of age in Brazil. Pesquisa Veterinária Brasileira, v.33, n.8, p.963-969, 2013. doi: 10.1590/ S0100-736X2013000800002.

DIAB, S.S. et al. Pathology of Clostridium perfringens type $\mathrm{C}$ enterotoxemia in horses. Veterinary Pathology, v.49, n.2, p.255-263, 2012. Available from: <http://www.ncbi.nlm.nih.gov/ pubmed/21502373>. Accessed: Out. 29, 2014.

DROLET R. et al. Necrohemorrhagic enterocolitis caused by Clostridium perfringens type $\mathrm{C}$ in a foal. Canadian Veterinary Journal, v.31. n.6, p.449-450, 1990. Available from: <http://www.ncbi. nlm.nih.gov/pmc/articles/PMC1480657/>. Accessed: Out. 29, 2014.

ENGSTRÖM, B.E. et al. Molecular typing of isolates of Clostridium perfringens from healthy and diseased poultry. Veterinary Microbiology, v.94, n.3, p.225-235, 2003. Available from: <http:// www.sciencedirect.com/science/article/pii/S0378113503001068>. Accessed: Out. 29, 2014. doi: 10.1016/S0378-1135(03)00106-8.

FARZAN, A. et al. An investigation into the association between cpb2-encoding Clostridium perfringens type A and diarrhea in neonatal piglets. Canadian Journal of Veterinary Research, v.77, n.1, p. 45-53, 2013. Available from: <http://www.ncbi.nlm. nih.gov/pubmed/23814355>. Accessed: Out. 29, 2014.

GIBERT, M. et al. Beta- 2 toxin, a novel toxin produced by Clostridium perfringens. Gene, v.203, n.1, p.65-73, 1997.

HAMMER, M.J. et al. Serological evaluation of a Clostridium perfringens type A toxoid in a commercial swine herd. Journal of Swine Health and Production, v.16, n.1, p.37-40, 2008.

HAZLETT, M.J. et al. Beta 2 toxigenic Clostridium perfringens type A colitis in a three-day-old foal. Journal of Veterinary Diagnostic Investigation, v.23, n.2, p.373-376, 2011. Available from: <http:// www.ncbi.nlm.nih.gov/pubmed/21398467>. Accessed: Out. 29, 2014.

HERHOLZ, C. et al. Prevalence of beta2-toxigenic Clostridium perfringens in horses with intestinal disorders. Journal of Clinical Microbiology, v.37, n.2, p.358-361, 1999. Available from: <http:// www.ncbi.nlm.nih.gov/pubmed/9889218>. Accessed:Out.29,2014. 
HOWARD-MARTIN, M. et al. Clostridium perfringens type $\mathrm{C}$ enterotoxemia in a newborn foal. Journal of the American Veterinary Medical Association, v.189, n.5, p.564-565, 1986. Available from: $<$ http://www.ncbi.nlm.nih.gov/pubmed/2875986>. Accessed: Out. 29, 2014.

JANG, S.I. et al. Relative disease susceptibility and clostridial toxin antibody responses in three commercial broiler lines coinfected with Clostridium perfringens and Eimeria maxima using an experimental model of necrotic enteritis. Avian Diseases, v.57, n.3, p.684-687, 2013. Available from: $<$ http://www.ncbi.nlm. nih.gov/pubmed/24283139>. Accessed: Out. 29, 2014.

JOST, B.H. et al. Association of genes encoding beta2 toxin and a collagen binding protein in Clostridium perfringens isolates of porcine origin. Veterinary Microbiology, v.115, n.1-3, p.173182, 2006a. Available from: <http://www.ncbi.nlm.nih.gov/ pubmed/16513295>. Accessed: Out. 29, 2014. doi: 10.1016/j. vetmic. 2006.01 .012

JOST, B.H. et al. Clonal relationships among Clostridium perfringens of porcine origin as determined by multilocus sequence typing. Veterinary Microbiology, v.116, n.1-3, 158165, 2006b. Available from: <http://www.ncbi.nlm.nih.gov/ pubmed/16650661>. Accessed: Out. 29, 2014. doi: 10.1016/j. vetmic. 2006.03 .025

KEYBURN, A.L. et al. Alpha-toxin of Clostridium perfringens is not an essential virulence factor in necrotic enteritis in chickens. Infection and Immunity, v.74, n.11, p.6496-6500, 2006. Available from: <http://www.ncbi.nlm.nih.gov/pubmed/16923791>. Accessed: Out. 29, 2014. doi: 10.1128/IAI.00806-06.

KEYBURN, A.L. et al. NetB, a new toxin that is associated with avian necrotic enteritis caused by Clostridium perfringens. PLOS Pathogens, v.4, n.2, p.26, 2008. Available from: <http://www. ncbi.nlm.nih.gov/pmc/articles/PMC2233674>. Accessed: Out. 29, 2014. doi: 10.1371/journal.ppat.0040026

KEYBURN, A.L. et al. Vaccination with recombinant NetB toxin partially protects broiler chickens from necrotic enteritis. Veterinary Research, v.44, p.54, 2013a. Available from: <http:// www.veterinaryresearch.org/content/44/1/54>. Accessed: Out. 29, 2014. doi: 10.1186/1297-9716-44-54

KEYBURN, A.L. et al. Maternal immunization with vaccines containing recombinant NetB toxin partially protects progeny chickens from necrotic enteritis. Veterinary Research, v.44, n.1, p.108, 2013b. Available from: <http://www.veterinaryresearch.org/ content/44/1/108>. Accessed: Out. 29, 2014. doi: 10.1186/12979716-44-108

KLAASEN, H.L. et al. Detection of the beta2 toxin gene of Clostridium perfringens in diarrhoeic piglets in The Netherlands and Switzerland. FEMS Immunology \& Medical Microbiology, v.24, n.3, p.325-332, 1999. Available from: <http://www.ncbi.nlm. nih.gov/pubmed/10397318>. Accessed: Out. 29, 2014.

LAWHON, S.D. et al. Frequency of resistance in obligate anaerobic bacteria isolated from dogs, cats, and horses to antimicrobial agents. Journal of Clinical Microbiology, v.51, n.11, p.3804-3810, 2013. Available from: <http:/www.ncbi.nlm. nih.gov/pubmed/24025899>. Accessed: Out. 29, 2014.

LEE, K.W. et al. Avian necrotic enteritis: experimental models, host immunity, pathogenesis, risk factors, and vaccine development.
Poultry Science, v.90, n.7, p.1381-1390, 2011. Available from: $<$ http:// www.ncbi.nlm.nih.gov/pubmed/21673152>. Accessed: Out. 29, 2014.

LEPP, D. et al. Identification of accessory genome regions in poultry Clostridium perfringens isolates carrying the netB plasmid. Journal of Bacteriology, v.195, n.6, p.1152-1166, 2013. Available from: $<\mathrm{http} / /$ www.ncbi.nlm.nih.gov/pubmed/23292780>. Accessed: Out. 29, 2014.

LONG, J.R. Necrotic enteritis in broiler chickens. I. A review of the literature and the prevalence of the disease in Ontario. Canadian Journal of Comparative Medicine, v.37, n.3, p.302-308, 1973.

LYHS, U. et al. Characterization of Clostridium perfringens isolates from healthy turkeys and from turkeys with necrotic enteritis. Poultry Science, v.92, n.7, p.1750-1757, 2013. Available from: $<$ http://www. ncbi.nlm.nih.gov/pubmed/23776261>. Accessed: Out. 29, 2014.

MCCOURT, M.T. et al. Sandwich ELISA detection of Clostridium perfringens cells and alpha-toxin from field cases of necrotic enteritis of poultry. Veterinary Microbiology, v.106, n.3-4, p.259-264, 2005. Available from: <http://www.ncbi.nlm.nih.gov/ pubmed/15778032>. Accessed: Out. 29, 2014. doi:10.1016/j. vetmic.2004.12.023.

MICLARD, J. et al. Clostridium perfringens beta-toxin targets endothelial cells in necrotizing enteritis in piglets. Veterinary Microbiology, v.137, p.320-325. Available from: <http://www. sciencedirect.com/science/article/pii/S0378113509000467> Accessed: Nov, 30. doi: 10.1016/j.vetmic.2009.01.025

MIYAMOTO, K. et al. Enterotoxigenic Clostridium perfringens: detection and identification. Microbes and Environments, v.27, n.4, p.343-349, 2012. Available from: $<$ http://www.ncbi.nlm.nih.gov/pubmed/22504431>. Accessed: Out. 29, 2014. doi: 10.1264/jsme2.ME12002.

NAUERBY, B. et al. Analysis by pulsed-field gel electrophoresis of the genetic diversity among Clostridium perfringens isolates from chickens. Veterinary Microbiology, v.94, n.3, p.257266, 2003. Available from: <http://www.ncbi.nlm.nih.gov/ pubmed/12814893>. Accessed: Out. 29, 2014. doi:10.1016/S03781135(03)00118-4.

NETHERWOOD, T. et al. Foal diarrhoea between 1991 and 1994 in the United Kingdom associated with Clostridium perfringens, rotavirus, Strongyloides westeri and Cryptosporidium spp. Epidemiology \& Infection, v.117, n.2, p.375-383, 1996.

NIILO, L. Clostridium perfringens Type C enterotoxemia. Canadian Veterinary Journal, v.29, n.8, p.658-664, 1988.

NOWELL, V.J. et al. Clostridium perfringens in retail chicken. Anaerobe, v.16, v.3, p.314-315, 2010. Available from: <http:// www.sciencedirect.com/science/article/pii/S1075996409001711>. Accessed: Out. 29, 2014. doi:10.1016/j.anaerobe.2009.11.004.

POPOFF, M.R.; BOUVET, P. Genetic characteristics of toxigenic Clostridia and toxin gene evolution. Toxicon, v.75, p.63-89, 2013. Available from: <http://www.ncbi.nlm.nih.gov/ pubmed/23707611>. Accessed: Out. 29, 2014. doi:10.1016/j. toxicon.2013.05.003.

RIDDELL, C.; KONG, X.M. The influence of diet on necrotic enteritis in broiler chickens. Avian Diseases, v.36, n.3, p.499503, 1992. Available from: <http://www.ncbi.nlm.nih.gov/ pubmed/1417581>. Accessed: Out. 29, 2014. 
SALVARANI, F.M. et al. Antimicrobial susceptibility of Clostridium perfringens isolated from piglets with or without diarrhea in Brazil. Brazilian Journal of Microbiology, v.43, p.1030-33, 2012.

SALVARANI, F.M. et al. Vaccination with recombinant Clostridium perfringens toxoids $\alpha$ and $\beta$ promotes elevated antepartum and passive humoral immunity in swine. Vaccine, v.31, n.38, p.4152-4155, 2013.

SCHÄFER, K. et al. Detection of Clostridium perfringens type C in pig herds following disease outbreak and subsequent vaccination. Veterinary Record, v.171, n.20, p.503, 2012. Available from: $<\mathrm{http} / /$ www.ncbi.nlm.nih.gov/pubmed/23100304>. Accessed: Out. 29, 2014.

SCHOSTER, A. et al. Presence and molecular characterization of Clostridium difficile and Clostridium perfringens in intestinal compartments of healthy horses. BMC Veterinary Research, v.29, n.8, p.94, 2012. Available from: <http://www.biomedcentral. com/1746-6148/8/94>. Accessed: Out. 29, 2014.

SLAVIĆ, D. et al. Antimicrobial susceptibility of Clostridium perfringens isolates of bovine, chicken, porcine, and turkey origin from Ontario. Canadian Journal of Veterinary Research, v.75, n.2, p.89-97, 2011. Available from: <http://www.ncbi.nlm.nih.gov/ pmc/articles/PMC3062930/>. Accessed: Out. 29, 2014.

SONGER, J.G. Clostridial enteric diseases of domestic animals. Clinical Microbiology Reviews, v.9, n.2, p.216-234, 1996.

SONGER. J.G.; GLOCK, R.D. Enteric infection of swine with Clostridium perfringens types A and C. Journal of Swine Health and Production, v.6, p.223-225, 1998.

SONGER, J.G.; UZAL, F.A. Clostridial enteric infections in pigs. Journal of Veterinary Diagnostic Investigation, v.17, n.6, p. 528-536, 2005. Available from: <http:/www.ncbi.nlm.nih.gov/ pubmed/16475510>. Accessed: Out. 29, 2014.

SPRINGER, S. et al. Occurrence and control of the Clostridium perfringens type A associated diarrhea of the suckling pigs with special consideration of the immunoprophylaxis. Tierärztliche Praxis. Ausgabe G, Grosstiere/Nutztiere, v.40, n.6, p.375-382, 2012.

TANSUPHASIRI, U. et al. Antimicrobial resistance among Clostridium perfringens isolated from various sources in Thailand. Southeast Asian Journal of Tropical Medicine and Public Health, v.36, n.4, p.954-961, 2005. Available from: $<$ http://www. ncbi.nlm.nih.gov/pubmed/21673152>. Accessed: Out. 29, 2014.
TAYLOR, D. Clostridial infections. In: STRAW, B.E. et al. Diseases of swine. Ames: Iowa State University, 1999. p.395-412.

TIMBERMONT, L. et al. Necrotic enteritis in broilers: an updated review on the pathogenesis. Avian Pathology, v.40, n.4, p.341-347, 2011. Available from: <http://www.ncbi.nlm. nih.gov/pubmed/21812711>. Accessed: Out. 29, 2014. doi: 10.1080/03079457.2011.590967.

TIMONEY, J.F et al. Antibody responses of mares to prepartum vaccination with Clostridium perfringens bacterin and beta2 toxin. Veterinary Record, v.157, n.25, p.810-812, 2005

UZAL, F.A. et al. Towards an understanding of the role of Clostridium perfringens toxins in human and animal disease. Future Microbiology, v.9, p.361-377, 2014. Avaliable from: $<$ http:// www.ncbi.nlm.nih.gov/pubmed/24762309>. Acessed: Out 30, 2014.

UZAL, F.A. et al. Clostridium perfringens type $\mathrm{C}$ and Clostridium difficile co-infection in foals. Veterinary Microbiology, v.156, n.3-4, p.395-402, 2012.

UZAL, F.A.; SONGER, J.G. Diagnosis of Clostridium perfringens intestinal infections in sheep and goats. Journal of Veterinary Diagnostic Investigation, v.20, n.3, p.253-265, 2008.

VAN IMMERSEEL, F. et al. Rethinking our understanding of the pathogenesis of necrotic enteritis in chickens. Trends in Microbiology, v.17, n.1, p.32-36, 2009. Available from: $<$ http://www. ncbi.nlm.nih.gov/pubmed/18977143>. Accessed: Out. 29, 2014.

VILEI, E.M. et al. Antibiotic-induced expression of a cryptic cpb2 gene in equine beta2-toxigenic Clostridium perfringens. Molecular Microbiology, v.57, n.6, p.1570-1581, 2005. Available from: <http:// www.ncbi.nlm.nih.gov/pubmed/21673152>. Accessed: Out. 29, 2014.

WEESE, J.S. et al. A prospective study of the roles of Clostridium difficile and enterotoxigenic Clostridium perfringens in equine diarrhoea. Equine Veterinary Journal, v.33, n.3, p.403409, 2001. Available from: <http://onlinelibrary.wiley.com/ doi/10.2746/042516401776249534/abstract>. Accessed: Out. 29, 2014. doi: $10.2746 / 042516401776249534$

WOLLSCHLÄGER, N. et al. Occurrence of Clostridium perfringens type $\mathrm{A}$ and type $\mathrm{C}$ in piglets of the Swiss swine population. Schweiz Arch Tierheilkd, v,151, n.8, p.377382, 2009. Available from: <http://www.ncbi.nlm.nih.gov/ pubmed/19653161>. Accessed: Out. 29, 2014. 